\title{
The Role of Meso-level Facilitating Conditions in the Emergence of Community-based Forest Management in Boudh District of Odisha
}

\author{
Kanna K. Siripurapu ${ }^{1, *}$, Joshua Wayland ${ }^{1}$, Hemanta K. Sahoo ${ }^{2}$, Martha E. Geores ${ }^{3}$ \\ ${ }^{1}$ Department of Geographical Sciences, University of Maryland, USA \\ ${ }^{2}$ Vasundhara, Plot No. \#1731/C, Das Mohapatra Complex, Opposite of Sai Villa PO: KIIT Campus, Dist: Khurdha Bhubaneswar, Odisha, \\ KIIT Square, Patia Station Rd, Patia, Bhubaneshwar, Odisha 751024, India \\ ${ }^{3}$ Department of Geographical Sciences, ENSP Land Use Adviser, Affiliate Faculty Department of Women's Studies, Affiliate Faculty \\ American Studies, University of Maryland, USA
}

Copyright $(2016$ by authors, all rights reserved. Authors agree that this article remains permanently open access under the terms of the Creative Commons Attribution License 4.0 International License

\begin{abstract}
The emergence and diffusion of community-based forest management (CBFM) in India over the past several decades has been of interest to scholars and natural resource managers alike. The prevailing view in the existing academic literature presupposes that CBFM arose spontaneously in individual villages, evolving into a grassroots movement that spread across districts and states. Previous studies of the phenomenon have focused on the micro-level (individual or community) and macro-level (national or global) factors that gave rise to CBFM; the role of meso-level (organizational) conditions in facilitating the rise and spread of CBFM has garnered significantly less attention. This study presents the results of structured interviews with key informants in 345 villages throughout the district of Boudh in the eastern Indian state of Odisha. Results suggest that meso-level conditions were vitally important in the development of CBFM. Nongovernmental organizations and the Indian Forest Department promoted CBFM and facilitated networking and sharing across villages, while informal networks between the villages expedited the diffusion of the new management model. The study also discusses the interaction between various meso, micro, and macro level facilitating conditions and concludes that the dynamics of CBFM in Odisha and in India more generally are significantly more complex than has previously been supposed.
\end{abstract}

Keywords Community-based Forest Management, Social Movements, India

\section{Introduction}

This paper investigates the emergence and diffusion of community-based forest management (CBFM) in the villages of Boduh district in the eastern Indian state of Odisha. CBFM refers to a broad range of strategies and practices for the management of forests, agroforests, and forest resources by local communities and small-holders; in India, approaches to CBFM vary according to local needs and customs, but generally involve detailed rules for the use of forests negotiated among members of locally established management organizations, representatives of local government and resource management agencies, and neighboring communities (Nayak, 2008). The existing literature on CBFM in Odisha and elsewhere in India conceptualize CBFM as a grassroots movement that arose independently among communities as a response to the environmental, economic, and cultural impacts of deforestation and loss of local access to forest resources and ecosystem services (Singh, et al., 2008; Sangita, 2008; Borgoyary, 2006; Singh, Sinha, and Mukherji, 2005; Pattanaik, 2002; Sarap, 2004; Singh, 2002; Singh, 2001). Previous studies have emphasized the role of macro-level stressors, such as population growth, national forestry policies, and land use change related to large-scale economic activities. At the micro-level, stressors include illegal harvesting of timber, over exploitation of fuelwood, uncontrolled grazing, and shifting patterns of grazing. Relatively little attention has been paid to the role of the organization and networks operating at the meso-level between the micro and macro scales (Li, 2012).

To investigate the structural conditions that enabled the development of CBFM in Odisha, interviews were conducted with key informants from 345 villages in the district of Boudh. Interview responses were analyzed within the micro-meso-macro (MMM) analytical structure described by Li (2012). The results suggest that meso-level conditions, including especially inter-village networks 
enabled by preexisting relationships between communities and non-governmental organizations (NGOs), played a much larger role in facilitating the rise and spread of CBFM in Odisha than has previously been supposed.

\section{Background}

The emergence of CBFM is generally seen as a response to the loss of local access to forest land and resources due to deforestation and failed national and state level forestry management. The primary drivers of deforestation in India in general and Odisha in particular include population pressure and the resulting loss of forest land for agriculture, fuelwood, and fodder; conversion of forest land for major development projects, such as irrigation infrastructure and reservoirs, roads, railroads, hydroelectric dams and other power plants, mines and quarries, and resettlement projects, among others; overexploitation of timber resources to supply raw material for paper and pulp industries, construction, fuelwood, and other uses; unregulated grazing by domestic livestock; changing patterns of agricultural cultivation; and degradation of forests from fire and pests (Kashyap, 1990).

Underlying these proximate drivers, some observers have identified the extension of state control over forest land by means of restrictive forestry policies and the hegemony of the powerful forest department as the ultimate driver of deforestation. According to this view, the exclusion of local communities from the management of forest land and resources has resulted in a system of de facto open access exploitation, leading to large scale encroachment and overexploitation by local communities and poachers (Mohanty, 2011; Vaidya, 2011; Vasundhara, 2010; Sarap and Sarangi, 2009; Borgoyary, 2006; Borgoyary, et al., 2005; Sarap, 2004; Sekhar, 2004; Sarin et al., 2003; Pattanaik, 2002; Poffenberger and Bhattacharya, 1996; Gadgil and Guha 1992). In Odisha, timber smugglers have played an outsized role in the districts of Athmalik, Baisapalli, Balasore, Balliguda, Bonai, Boudh, Daspalla, Dhenkanal, Keonjhar, Pallahara, Rayagada, Satkosia, and Simlipal, decimated dense forests to meet the demand for construction materials in the cities (Riyan, 2015; The New Indian Express, 2014; Mishra, 2012; Odisha Sun Times Bureau, 2011; NDTV, 2010).

The prevailing view of CBFM in Odisha is that local communities began to spontaneously reinstate traditional forms of forest management as a response to exclusion and deforestation beginning in the 1960s (Singh, et al., 2008; Borgoyary, 2006; Singh, Sinha, and Mukherji, 2005; Pattanaik, 2002). During the 1970s and 1980s, CBFM evolved into a grassroots movement that spread rapidly across the villages of the state (Sarin 1994; Sarin 1995; Poffenberger 1995; Sarin 1996; Vasundhara 1996; Khare 1998; Jeffery and Sundar, 1999; Pattanaik 2002; Nayak and Berkes, 2008; Sangita, 2008; Sarap and Sarangi, 2009; Siripurapu, 2010; Mohanty, 2011; Singh, et al., 2008; Sangita, 2008; Borgoyary, 2006; Singh, Sinha, and Mukherji,
2005; Pattanaik, 2002). To date, studies of CBFM in Odisha have focused on the macro-level facilitating conditions - what McAdam and Snow (1997) call "strains, or characteristics of the social structure that create grievances; and opportunities, or characteristics of the external environment that encourage movement formation." Relatively little attention has been paid to the role of meso-level structures, such as inter-community organizations and networks. This paper seeks to identify the main conditions at the macro, meso, and micro levels that facilitated the emergence and diffusion of CBFM in Odisha.

\section{Methods}

The study area for this study is located within the administrative district of Boudh (or Baudha) in the eastern Indian state of Odisha. The study area comprises of 1186 (Inhabited - 1115, Uninhabited -71) villages (of which 345 villages are actively engaged in CBFM). Boudh is located in central Odisha, bordered on the north and west by the Mahanadi River, beyond which are the districts of Bolangir, Subarnapur, and Angul. To the south are the districts of Nayagarh, Phulbani, and Kalahandi. The district covers an area of approximately 3445 square kilometers. Approximately 1277 square kilometers, or about 37 percent of the total area, is classified as forest; the forested area is concentrated in the southern and southwestern areas of the district (see Map 1). Boudh has a total population of approximately 441,162 and a population density of around 142 people per square kilometer. The economy in the district is driven primarily by agriculture and small scale industries, including food based, metallurgical based, textile based, forest based, and chemical based industries. Paddy rice cultivation is the predominant agricultural activity and approximately 64,000 hectares are dedicated to paddy farming, out of a total cultivable area of 85,000 hectares. The mining industry is also an important component of the district economy (Govt. of Odisha, 2015). The state has one of the highest tribal populations in India, with nearly $25 \%$ of the total population identifying as tribal.

Boudh was selected for the present study as there is lack of information on the exact number of villages that are engaged in CBFM and accessibility due to presence of strong network of district level forest federation. Standardized key informant interviews, comprised of open and close ended questions, were conducted with village chiefs, executive members of the forest protection committee, and village elders in 345 villages throughout the Boudh district. Interviews were conducted in Odiya, the official local language of the district. The interview questionnaire was developed in consultation with forestry experts and was tested in an extensive pilot study. Follow up meetings were conducted with interview participants to ensure the reliability of the responses. Questionnaire items focus on the development of CBFM in target villages, emphasizing the drivers of CBFM development and diffusion. 


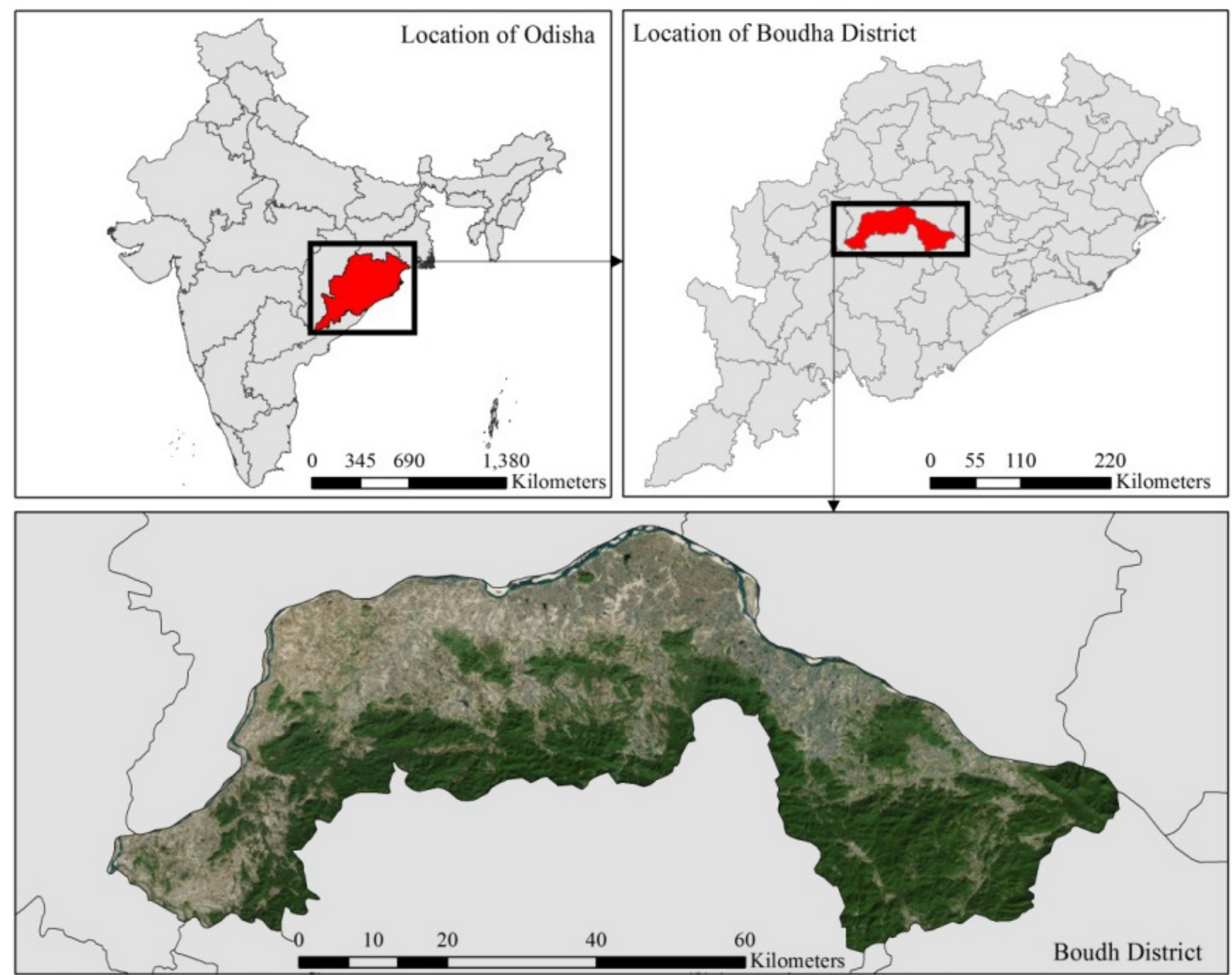

Service Layer Credits: Source: Esri, DigitalGlobe, GeoEye, i-cubed, USDA, USGS, AEX, Getmapping, Aerogrid, IGN, IGP, swisstopo, and the GIS User Community

The responses to the interview questions were considered in terms of a MMM analytical structure. MMM theories address broad (in terms of both time and space), society-wide patterns and historical changes at three scales or levels (Fuller, 2014). Micro-level structures, which are associated with individual actors and persons in organizations, and macro-level structures, associated with states and social institutions, have been widely examined in the economic, sociological, and geographic literature. Meso-level structures, present at intermediate levels of organizations, on the other hand, have been comparatively overlooked in the existing literature ( $\mathrm{Li}, 2012)$. Li (2012) points that it was only recently that scholars paid attention to the significance of meso-level and that very little attention has been paid to the integration of the three levels in studies on social phenomenon. This has been true of the study of CBFM in India, which has typically focused on either micro-politics within individual communities, or macro-level drivers of deforestation and exclusion.

\section{Results}

Macro-level facilitating conditions

A number of reasons at the macro-level have been suggested for the emergence of CBFM in Odisha. These include population pressure, diversion of forest land for development projects, overexploitation of forest by the state and industries for revenue generation, increase in the intensity of shifting cultivation by indigenous population, restrictive and anti-poor forest polices, and the resulted local communities' loss of ownership and control over forest land (Mohanty, 2011; Vaidya, 2011; Vasundhara, 2010; Sarap and Sarangi, 2009; Borgoyary, 2006; Borgoyary, et al., 2005; Sarap, 2004; Sekhar, 2004; Borgoyary, et al., 2005; Sarin et al., 2003; Pattanaik, 2002; Poffenberger and Bhattacharya, 1996; Gadgil and Guha 1992; Kashyap, 1990). 


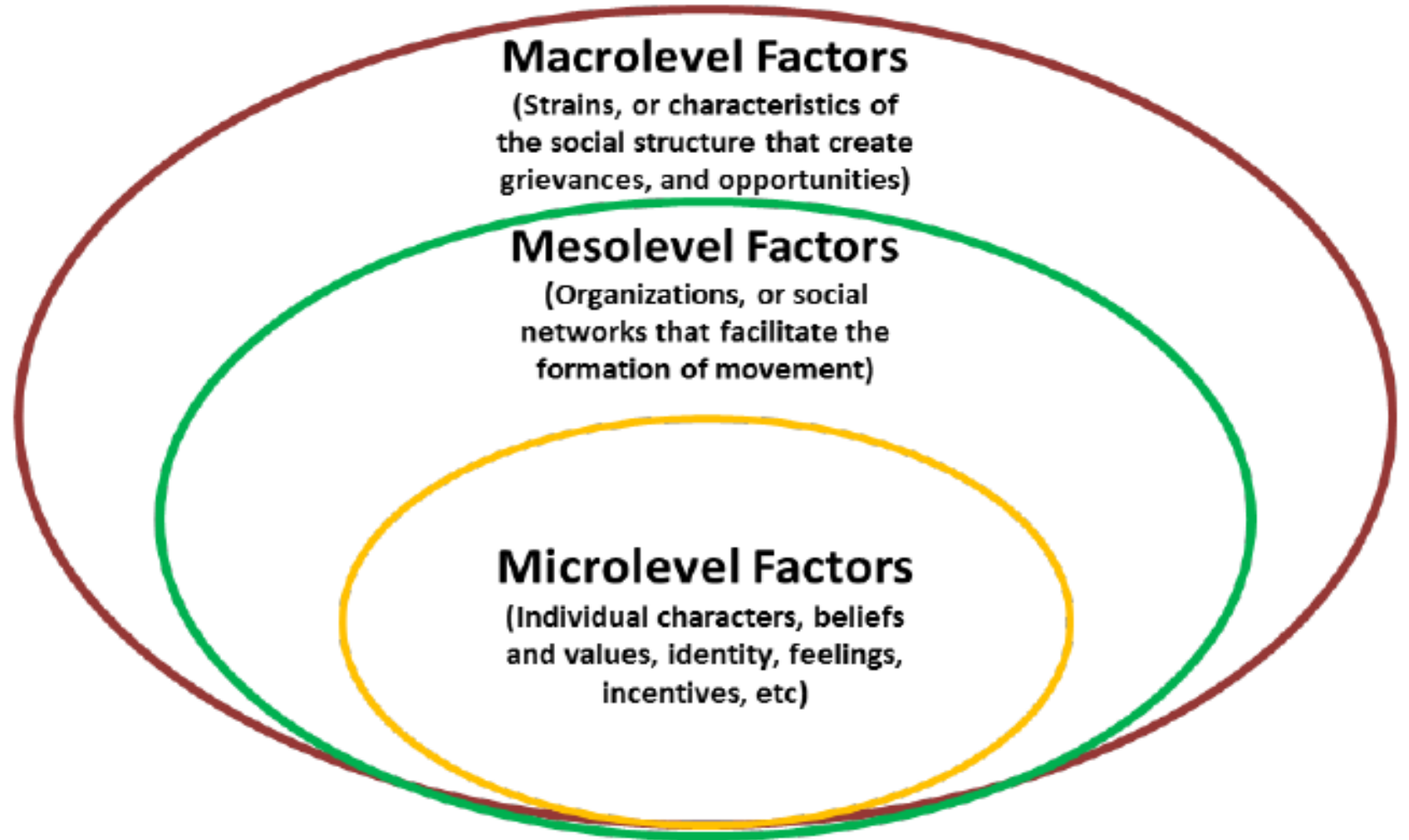

Source: Fuller, 2014; McAdam and Snow, 1997.

Figure 1. Showing Levels of Analysis in Investigating the Formation of Social Movements

The two main indicators of absolute scarcity of forest resources are population and forest area. The population of Odisha has grown at a somewhat lower rate than elsewhere in India, increasing from approximately 14 million in 1951 to 41 million in 2011 (Behera, 2006; GOI, 2011). During the same period, forest cover declined from more than 66,000 square kilometers to less than 54,000 square kilometers (Patro, and Jena, 2008; ENVIS, 2015). The study region of Boudh exhibits typical shows a similar trend like rest of Odisha in terms of population growth. Boudh had a population of a quarter of a million during 1972-81 but grew to nearly half a million in 2011 (The Indian Census, 2011). The recorded forest cover of Boudh during the years between 1972 and 1981 was approximately 1697 square kilometers, or approximately $55 \%$ of the total geographic area; in 2015 , forests covered approximately 1277 square kilometers of Boudh, or about $41 \%$ of the total geographic area of the district (ENVIS, 2015; FSI, 2009; MoEF, 2007; see Figure 2).

In a demographic/structural model of state breakdown, Goldstone (1991) argues that social stability has more to do with government policy, capital availability, and local organization than with the simple arithmetic of bodies and land. Goldstone (1991) points out that development policies often focuses on raising GDP per capita, but an increase in GDP may not necessarily brings social stability because a lagging agricultural sector, and problems in the distribution of income and taxation can still produce a crisis.

Corroborating Goldstone's (1991) argument that development policies often focuses on GDP was the National Commission on Agriculture (NCA) of India, report (1976), which advocated for commercialization of forests in India as a panacea to boost the economy and feed its ever increasing population. In this process the NCA of India completely ignored the rights of indigenous and other forest-dwelling communities and their dependence on the forests for subsistence and survival. The NCA asserted that 'production of industrial wood has to be the raison d'etreof the existence of forests' (GOI 1976: 32-33). This commercial bias was evident in the statement that 'free supply of forest products to the rural population and their rights and privileges have brought destruction to the forests and so it is necessary to reverse the process'. The NCA recommended that the revised national forest policy be based on important needs of the country. All forest lands should be classified into protection forests, production forests and social forests. The NCA gave highest priority to the production forests and the lowest priority to social forests. The commission recommended that the objective of forest management should be that 'each hectare of forest land should be in a position to yield a net income of many more times than is being obtained at present'. The NCA recommended the enactment of a revised all-India forest Act (Vaidya, 2011; Saxena, 1997). On the other hand, Siripurapu (2010) in the case study of nine CBFM villages in Odisha found that the increase in population has lead not only to the division of communal agriculture lands among the villagers but also increase in the encroachment and conversion of more forest land into agriculture land to feed the increasing population. 


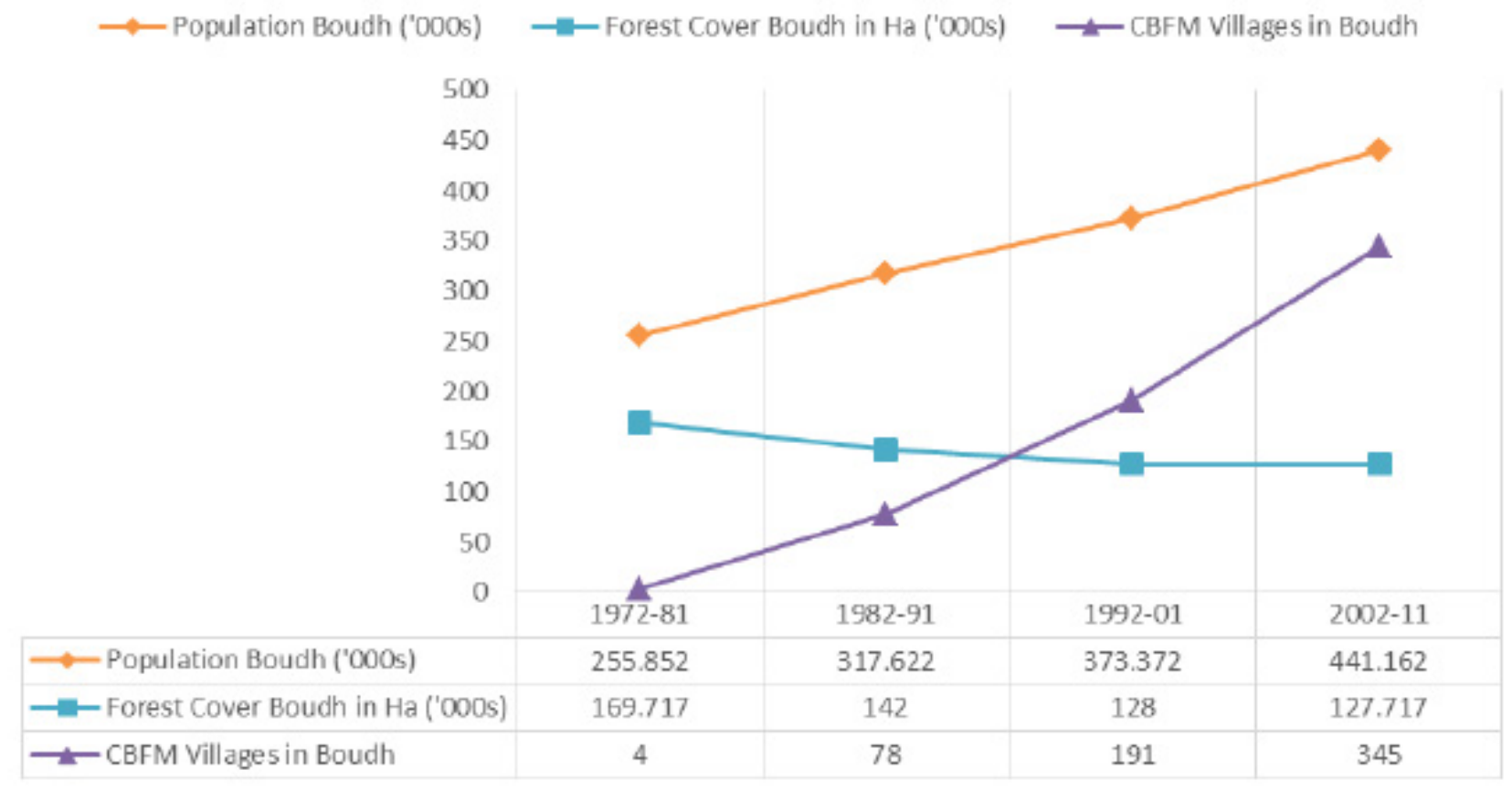

Various sources: ENVIS, 2015; FSI, 2009; MoEF, 2007; The Indian Census, 2011.

Figure 2. Shwoing population growth, forest cover change and increase in the number of CBFM villages in Boudh

For instance, the Forest Policy 1952 of independent India declared that rural population should not be allowed to use forests at the expense of national interest, and the national interest was identified with economic growth, industries, communication and defense. The First Plan in 1952, perceived the mixed-natural forests as "low"-value forests, hence it directed the conversion of all such forests to "high"-value monocultures plantations of commercial species like teak (Tectona grandis) and eucalyptus species (Eucalyptus sp.). The conversion of mixed natural forests to monoculture plantations, the commercialization and commodification of forest resources, and restrictions on the rural and forest dependent communities due to them perceived as a threat to the national interests, has received a new leash with the approval of NCA (1976) report (Saxena, 1997). As per the estimates of to the National Remote Sensing Agency, the annual average deforestation rate in India between 1975 and 1982 was 1.3 million hectares, representing the degradation of 10.4 million hectares of closed forest in India (Poffenberger and Mc Gean, 1996). The revenue maximization drive of the government has led to the replacement of large tracts of natural mixed forests with monoculture timber species. The Common Wealth Foundation Report (2008) estimates that an area of 3.2 million ha is now covered under plantations in India. The replacement of mixed forests with monoculture plantations, diversion of forest resources to industries, conversion of large tracts of forests to non-forest use, over exploitation of forests for revenue generation, has rapidly resulted in both deforestation and forest degradation in India. Furthermore, it also resulted in the decrease and availability of fuelwood and poles for the ever increasing rural and resource dependent population. In addition, the restrictions on the access to forest resources for the resource dependent people due to anti-poor and restricted forest policies have left them totally deprived of the resources that are crucial for their subsistence and survival (Vaidya, 2011, Sahu, 2010; Common Wealth Foundation Report, 2008; Kant, et al., 2008; Borgoyary, et al., 2005; Vasundhara, 2005; Gadgil and Guha 1992; Poffenberger and McGean, 1996; Saxena, 1997).

The problem of increasing population on one side (population of India grew from 345 million in 1947 to 1.2 billion in 2013), (GOI, 2011; Srinivasan, 2004) and the anti-poor and pro-industrial forest policies on the other have led not only to increase in deforestation but also forest degradation.

During the key informant interviews, participants were asked to identify the reasons that their community initiated CBFM. Two of the choices offered to respondents as potential reason for initiating CBFM deal directly with macro-level conditions. These were "environmental conservation" and "wildlife conservation." Out of the 345 participating villages, 21 villages $(6 \%)$ cited environmental conservation as a reason for initiating CBFM and 5 villages $(1.5 \%)$ identified wildlife conservation. Other response choices, such as "scarcity of fuelwood" relate indirectly to macro-level conditions as experienced by communities at the micro-level, and are discussed in detail in the following section.

\section{Micro-level facilitating conditions}

The reasons for initiation of CBFM by the local communities in Boudh have varied from scarcity of wood for making agriculture implements, environmental conservation, scarcity of fuelwood, livelihood, scarcity of building material, and wildlife conservation. The results of the key 
informant interviews suggest that the local communities of Boudh initiated CBFM as they suffered from resource scarcity especially to meet their energy and agricultural needs at the micro-level. Out of all the above reasons the scarcity of fuelwood and wood for agriculture purposes were reported as the most important reasons by the local communities of Boudh to initiate CBFM. Out of 345 villages, 254 villages $(73.6 \%)$ reported scarcity of fuelwood and wood for making agriculture implements as the reason for initiation of CBFM, $30(8.7 \%)$ villages reported only fuelwood and 17 village (5\%) reported only wood for making agriculture implements as the main reason for initiation of CBFM. A total of 21 village $(6 \%)$ reported environmental conservation (EC) as the reason for initiation of CBFM. Out of the remaining, 7 (2\%) villages reported livelihood, 6 villages $(1.7 \%)$ reported building material, 5 $(1.5 \%)$ wildlife conservation, $3(0.9 \%)$ reported fuelwood and building materials and only $2(0.6 \%)$ reported fuelwood and livelihood as the main reason for initiation of CBFM in Boudh (Fig. 3). In addition to the forestry department, NGOs, and neighbouring villages, it was also observed that a single individual mainly local leader has also played a significant role in the emergence of CBFM in Boudh. Around 4 (1\%) villages have reported to have initiated CBFM due to motivation from a local leader.

\section{Meso-level facilitating conditions}

The most interesting findings from the analysis of the interview results pertain to the role of organizations and institutions that are operative between the more widely studied micro and macro scales. At the meso level, extra-local organizations, including NGOs and government agencies, were identified as essential facilitating conditions for the emergence and diffusion of CBFM.

Although many studies from other regions of Odisha and elsewhere in India have concluded that CBFM emerged spontaneously from the voluntary initiatives of local communities, the results of the present study shows that only 4 villages (1\%) out of 345 CBFM villages in Boudh initiated CBFM voluntarily without receiving any support from outside actors. A plurality of 132 villages (38\%) in Boudh initiated CBFM with support from NGOs. An additional 89 villages $(26 \%)$ reported having initiated CBFM with encouragement from the forest department. The influence of the neighboring villages was also found to be an important factor; around 94 villages $(27 \%)$ were motivated by interaction with neighboring villages.

The role of outside actors in motivating the local communities of Boudh to initiate CBFM was found to have increased significantly over time. The earliest example of CBFM among the villages surveyed, initiated in approximately 1975 , was encouraged by an NGO. During the 1970 s, approximately $25 \%$ of new CBFM initiatives were influenced by NGOs. This percentage rose in the following decades, to approximately $36 \%$ between 1982 and 1991, 38\% between 1992 and 2001, and 40\% between 2002 and 2011(see Figures 4, 5, and 6). Among villages that implemented CBFM between 1972 and 1981, approximately $25 \%$ were influenced by neighboring villages; between 1982 and 1991 and between 1992 and 2001, this percentage increased to $20 \%$ and $33 \%$, respectively, before declining to approximately 27\% between 2002 and 2011 (see Figures 4, 5, and 6). Conversely, the impact of forestry department to influence CBFM implementation appears to have declined over time. The forestry department motivated $50 \%$ of villages that implemented CBFM between1972 and 1981, $27 \%$ of villages that initiated CBFM between 1982 and 1991, $23 \%$ of villages that initiated CBFM between 1992 and 2001, and approximately $27 \%$ of villages that initiated CBFM between 2002 and 2011 (see Figures 4, 5, and 6).

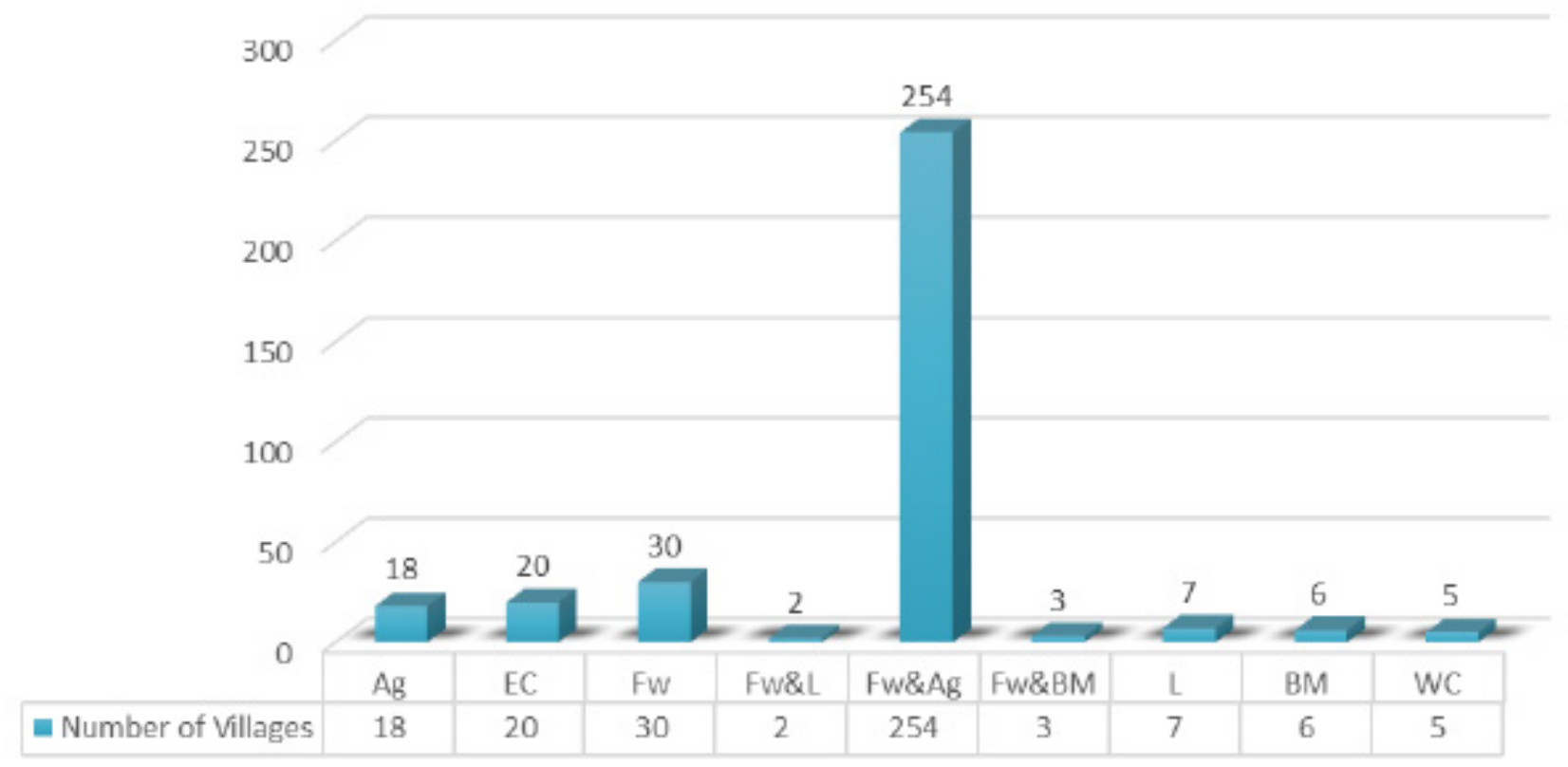

Figure 3. Reasons for the initiation of CBFM at different villages in Boudh 


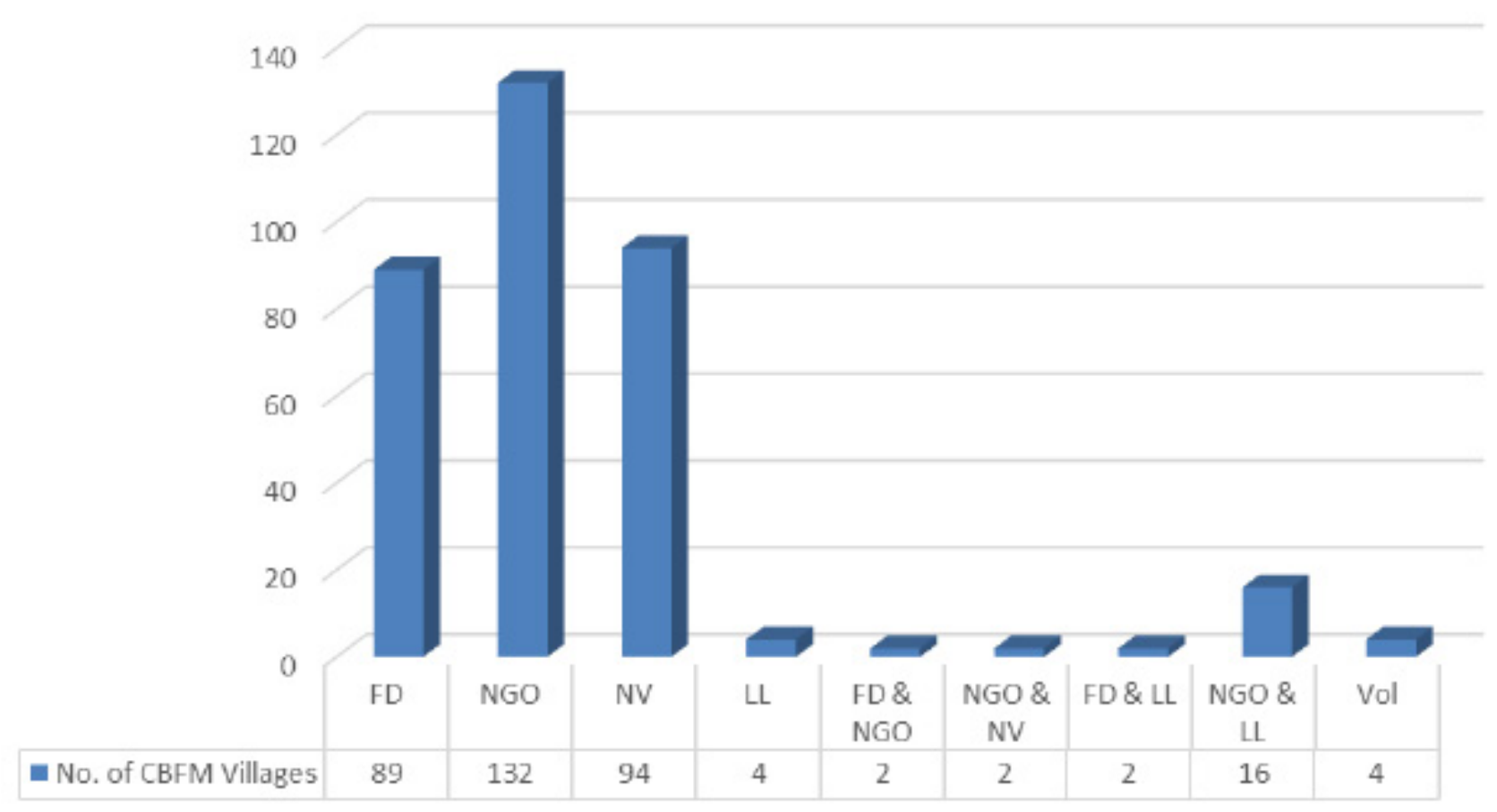

Figure 4. The number of villages in Boudh encouraged by different exteranl actors/organizations to initiate CBFM

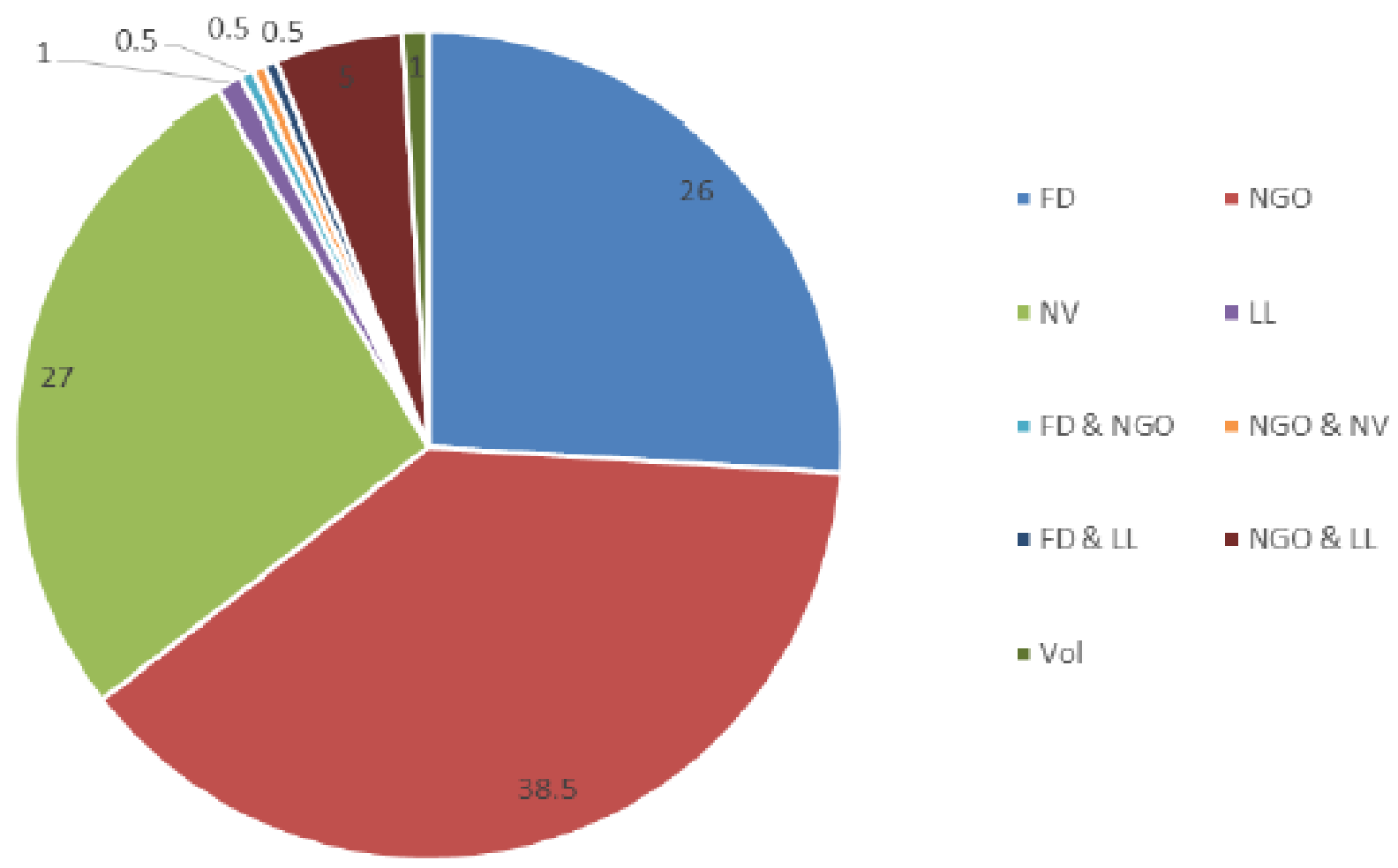

Figure 5. The $\%$ of vilages in Boudh motivated by external actors/organizations to initiate CBFM 


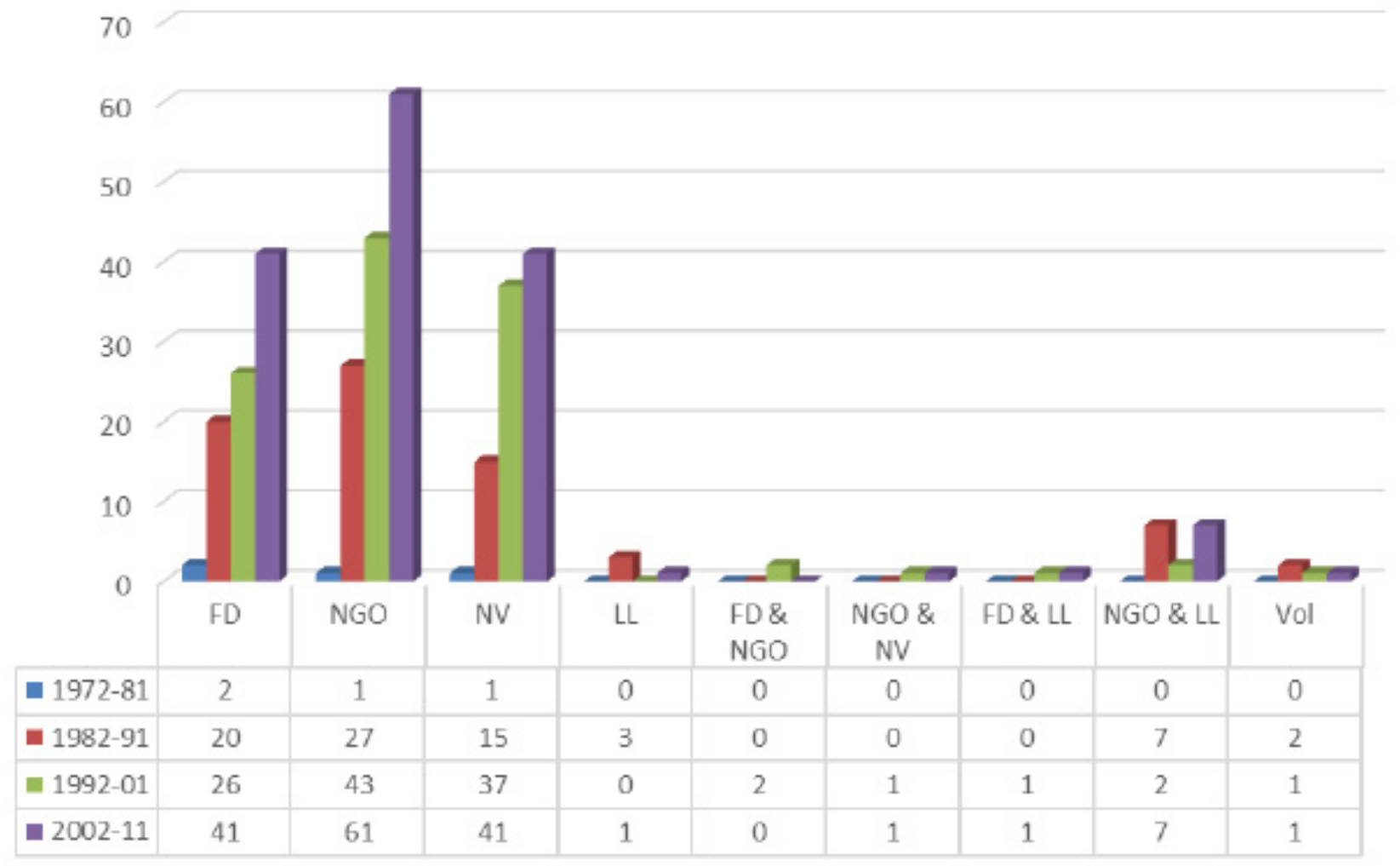

Figure 6. The number of villages motivated by different external actors on a temporal scale

\section{Interactions}

In the villages of the Boudh district, NGOs, the forestry department, neighboring villages, and local leaders have collaborated with each other in different combinations to motivate the villagers to initiate CBFM. For instance, 2 villages $(0.5 \%)$ reported that they initiated CBFM due to motivation from NGOs and the forestry department, 2 villages $(0.5 \%)$ reported that they initiated CBFM due to motivation from the forestry department and a local leader, 2 villages $(0.5 \%)$ reported having initiated CBFM due to motivation from NGOs and neighboring villages, and 16 villages $(4.6 \%)$ reported to having initiated CBFM due to motivation from NGOs and a local leader. These findings are consistent with studies conducted on CBFM in three districts of Kandhamal, Mayurbhanj and Koraput districts of Odisha, which found that local NGOs, the forestry department, and the local communities themselves have been instrumental in the initiation of CBFM movement in Odisha (Singh et al., 2008; Singh, Sinha, and Mukherji, 2005).

\section{Discussion}

Meso-level facilitating conditions, in the form of NGOs and inter-village networks, were found to have played particularly important roles. The forestry department, a national agency, was also found to have promoted CBFM implementation in many villages. CBFM has been described as a grassroots movement (Christiansen, 2009; De la Porta \&
Diani, 2006; Macionis, 2001; Freeman and Johnson, 1999; Miller, 1999). "A grassroots movement is not necessarily organized by any political forces, instead it emerges due to some pressing issue that a local community feels the need to be changed or enhanced" (EDF, 2014, p.2).

Work by Sangita (2008) and others offer insight into the process by which the identified conditions - and the relationships between those conditions-facilitated the emergence and spread of CBFM in the Boudha district and throughout Odisha. Sangita argues that villages implementing CBFM mobilized social capital by means of established networks to motivate neighboring villages and promote the adoption of CBFM (see also Das, 2005; Lin, 2002; Woolcock, 2000; Putnam, 1993). These networks included not only those explicitly dedicated to forestry or natural resource management, but also economic development NGOs and youth groups, among others. The familiarity of the local communities with the NGOs and other organizations may have helped to build confidence and trust, increasing the speed with which CBFM spread throughout the district (Sangita, 2008). NGOs facilitated the creation of platforms necessary for frequent interaction among different stakeholders group and, in association with local networks and forest federations, enabled the dissemination of information related to CBFM to local communities and forest user groups.

It was through the NGOs that local civic and government leaders were introduced to the principles of CBFM. NGOs organized awareness camps, hosted conferences and training 
programs, and published newsletters to inform those leaders about the rights and responsibilities of forest people, explain the policies and laws applicable to CBFM, and share success stories from villages where CBFM had been successfully implemented (Sangita, 2008). They were also instrumental in organizing parades (known locally as padayatras) from village to village, public meetings and forums, picketing and protest movements to create awareness among the local communities of Odisha on the impacts of deforestation and environmental pollution and the need for afforestation, forest and wildlife conservation (Sangita, 2008).

Furthermore, the state level NGO networks in Odisha have been receiving both financial and technical assistance from international donor organizations like OXFAM, Ford Foundation, and SPWD, for organizing conferences, awareness camps, training programmes, exposure trips, preparing monographs, conducting studies, and publishing newsletters, which are vital to strengthen the grassroots initiatives such as CBFM in Odisha. International donor agencies like OXFAM, Ford Foundation played a vital role in the establishment of OJM and strengthening the local NGO networks by providing financial and technical assistance (Sangita, 2008; Borgoyary, 2006).

Sangita (2008) argues that the government of India has adopted legal instruments (rules/constitutional status), individual or group incentives and training programs for mobilizing the social capital for the implementation of state promoted, external donor driven participatory forest management programs like the Joint Forest Management (JFM) across the sub-continent. Although that is true in the context of JFM, but it is not clear at this point on the instruments used by the Odisha forest department to motivate the local communities and mobilize social capital to initiate CBFM in Odisha. Further study is necessary to investigate the instruments used by the forest department to motivate the local communities of Odisha to initiate CBFM.

The concept of participatory forest management networks (PFMN) in Odisha arose for the first time in the year 1982, when a group of 22 villages in the Mayurbhanj district came together to form a local community organization dedicated to protecting the forest and rehabilitating the surrounding degraded hillocks (Borgoyary, 2006). In a decade, in the year 1991, this local initiative developed into a district level participatory forest network in Mayurbhanj (Borgoyary, 2006). By 1995, the concept of district level forums had spread to the other districts of Odisha. With the support of Oxfam, an international donor NGO, the movement gained momentum and developed into a state level forest federation, the Odisha Jungle Manch (OJM) in 1999 (Siripurapu, 2013; Sangita, 2008; Borgoyary, 2006; Sarap, 2004).

OJM is now the apex state level forum constituting NGOs, and local community leaders, facilitated and supported by both the district level NGOs and the state level NGOs, namely Regional Centre for Development Cooperation (RCDC) and Vasundhara (Borgoyary, 2006). There is a strong presence of the participatory forest management networks in the districts of Deogarh, Gajapati, Kalahandi,
Koraput, Nayagarh, Nawarangpur, Kandhamal, Rayagada, Sambalpur, Sundargarh, as well as Boudh, the study area in Odisha (Sarap, 2004).

The networks at cluster or forest block level are mobilizing the local communities for collective action and management of community-based forests. The federations of different regions have been striving towards strengthening the community-based forest protection and management arrangements in Odisha (Sarap, 2004). As a part of these efforts the state level federation, OJM has set certain objectives to strengthen and promotion of CBFM to new areas within the state. The objectives of OJM are: (a) To spread the idea of community-based forest protection to newer villages, building unity, and cooperation in cluster committees; (b) Inter and intra network conflict resolution; if unresolved at the local levels; (c) Critique the State forest and development policies and liaison and lobby with the government to make necessary changes to the forest and development policies which are perceived to endanger CBFM, local culture and livelihoods; and (d) Dissemination of information through publication of a newsletter named "Thengapali" in the regional language as a service to provide information and links with its constituency (Raju, 1998). Although the present study lacks empirical evidence to suggest the impact of forest federations of Odisha in the promotion and spread of CBFM to new villages in Odisha, but the increase in the number of CBFM villages in Odisha which corresponds to the development and spread of forest federation across the state suggests that there could be a correlation between the two.

\section{Conclusions}

The results presented above offer insight into the conditions that gave rise to the emergence and diffusion of CBFM in the district of Boudh and in the state of Odisha more generally. Although macro-level structures-including the failure of the state to effectively management forests and population growth-and micro-level factors, such as the shortage of wood for use as fuel or for making agricultural implements, undoubtedly played a role in the development of CBFM, the findings suggest that meso-level conditions present in the study area were a critical condition, and one that has been largely overlooked and under-analyzed in the existing literature. Outside actors, including NGOs and the Forest Department, appear to have been instrumental in promoting CBFM in Boudh communities, while networks between neighboring villages facilitated the spread of CBFM across the district. Contrary to the common perception of CBFM as a grassroots phenomenon that arose spontaneously and independently in villages in response to mismanagement of forest resources and dwindling resource availability, the results of the present study indicate that CBFM was actively encouraged by inter-village organizations and networks among the communities themselves. Future studies of CBFM in India should be cognizant of the function of 
meso-level conditions in addition to the more widely recognized micro and macro level factors. Because meso-level conditions have garnered relatively little scholarly attention, the motivations and organizational dynamics of actors such as the Forest Department and the NGOs that promoted CBFM in Boudh would be a promising avenue for future research.

\section{Acknowledgements}

The authors would like to thank Ford Foundation, New Delhi, India, for funding the present study. Many thanks to the forest federation of Boudh, Odisha and representatives of the forest federation of Boudh, Odisha, for extending support and helping in data collection for the present study. Many thanks to the villagers who participated in the study and very patiently shared the details and experiences with us. Thanks to Ms. Ranjitha Pattanik, Vasundhara, India, for translating the questionnaires from the local language Odiya to English and also organizing the data. Last but not the least, many thanks to the anonymous reviewers of this article for their valuable comments.

\section{REFERENCES}

[1] Agrawal, A. 2001. Common Property Institutions and Sustainable Governance of Resources. World Development 29: $1649-1672$

[2] Agarwal, A. and Yadama, G. N. 1997. How do Local Institutions Mediate Market and Population Pressures on Resources? Forest Panchayats in Kumaon, India. Development and Change Vol. 28, 435-465. Institute of Social Studies. Oxford OX4 1JF, UK.

[3] Abernathy, V. 1993. Population Politics: The Choices that Shape Our Future. New York: Plenum Press/Insight Books.

[4] Behera, C. 2006. 'Orissa Resettlement and Rehabilitation Policy 2006: A Contribution towards an Immanent Critique, '2006. Accessed online: http://chittabehera.com/Re habilitation/

Orissa\%20RRPolicy\%2006-\%20A\%20Ccritique.pdf

[5] Ballabh, V., Balooni, K. and Dave, S. 2002. Why local resources management institutions decline - A comparative analysis of Van (Forest) Panchayats and forest protection committees in India. World Development. 30: 2153-2167.

[6] Borgoyary, M. 2006. Understanding the Role of Networks as Connecters in Bridging the Research Policy Gap in Participatory Forest Policy Development in India. (In) JBIC Institute, Discussion paper, no.12.

[7] Borgoyary, M., Saigal, S., and Peters, N., 2005. Participatory Forest Management implementation in India: A review of policies and implementation. Springate-Baginski, O., (eds.) Winrock International India.

[8] Christiansen, J. 2009. Four Stages of Social Movements.
Social Movements \& Collective Behavior, Four Stages of Social Movements. EBSCO Research Starters, EBSCO Publishing Inc.

[9] Common Wealth Foundation, 2008. Commonwealth Forests An overview of the Commonwealth's forest resources. Common Wealth Forestry Association, 2007.

[10] Das, R. 2005. Rural Society, the State and Social Capital in Eastern India: A Critical Investigation. The Journal of Peasant Studies, 32:1, 48-87

[11] De la Porta, D. \& Diani, M. 2006. Social movements: An introduction (2nd Ed). Malden MA:Blackwell Publishing.

[12] Ehrlich, P and Ehrlich, A. 1991. The Population Explosion. New York: Touchstone, Simon and Schuster Inc.

[13] Environmental Information System (ENVIS), 2015. Forest Resources. ENVIS Centre of Odisha's State of Environment. Ministry of Environment, Forests \& Climate Change, Govt. of India. Accessed online: http://www.orienvis.nic.in/index1. aspx?lid=29\&mid=1\&langid=1\&linkid= 27

[14] Environmental Defense Fund (EDF) 2014. Diversity Strategy and Recommendations. Environmental Defense Fund, NY, USA.

[15] Freeman, J. \& Johnson, V. 1999. Waves of protest: Social movements since the sixties. Lanham, Maryland: Rowman \& Littlefield.

[16] Forest Survey of India (FSI), 2009. India State of Forest Report 2009. Ministry of Environment and Forests, India. Accessed online: http://www.indiaenvironmentportal.org.in/f iles/SFR2009-ExecSummary-FINAL.pdf

[17] Fuller, A. A. 2014. Changing the world: an introduction to social movements. Creative Commons Attribution. Accessed online:

http://cnx.org/contents/2a7412e5-8187-43bf-b8dd-48e795ae 951a@1.3:52/Fuller's-Introduction-to-Socio

[18] Gadgil, M., and Guha, R. 1992. 'This Fissured Land - An Ecological History of India', Oxford University Press, Delhi.

[19] Goldstone, J. A. 1991. A Demographic/Structural Model of State Breakdown. In Goldstone, J. A., Revolution and Rebellion in the Early Modern World. Berkeley: University of California Press, Pp.459-475.

[20] Government of Odisha, 2015. District Portal Boudh. Accessed online: http://ordistricts.nic.in/district profile/dist glance.php

[21] Government of India (GOI), 2011. Orissa Population Census Data 2011. The Census Organization of India, India. Accessed online: http://www.census2011.co.in/census/state/ orissa.html

[22] Government of India (GOI), 1976. Report of the National Commission on Agriculture, Part IX, Forestry. Department of Agriculture and Cooperation, Government of India, New Delhi.

[23] Japan bank for international cooperation (JBIC), 2006. Understanding the Role of Networks as Connecters in Bridging the Research Policy Gap in Participatory Forest Policy Development in India. JBIC Institute, Discussion paper, no.12. 
[24] Jeffery, R. and N. Sundar (eds.). 1999. A New Moral Economy for India's Forests? New Delhi: Sage Publications.

[25] Jodha, N. S. 1985. Population Growth and the Decline of Common Property Resources in Rajasthan, India. Population and Development Review, Vol. 11, No. 2, pp. 247-264

[26] Judith, E. O, Kinuabeye, U, J and Eja, I, E. 2011. Impact of Population Growth on Forest Resource Degradation in Ikom Local Government Area. Universal Journal of Management and Social Sciences Vol. 1, No.1.

[27] Kant, P., Singh, P. P., Shahabuddin, G., and Jasrotia, R. S. 2008. India: Bringing a third of the land under forest cover. In: Don Koo Lee (Editor), 2008. Keep Asia Green, Volume III "South Asia". IUFRO World Series Volume 20-III. www.iufro.org/download/file/7400/5122/India_pdf/

[28] Kashyap, S. C. 1990. National Policy Studies. Tata McGraw-Hill Publishing Company Limited, for The Lok-Sabha Secretariat, New Delhi.

[29] Khare, A., Sarin, M., Saxena, N.C., Palit, S., Bathia, S., Vania, F., and Satyanarayana, M. 2000. Joint forest management: Policy, practice and prospects. Policy that works for forests and people series. No. 3. London: International Institute for Environment and Development and Earthscan Publications.

[30] Khare, A. 1998: Community based conservation in India. In: Kothari et al. (eds.) Communities and Conservation. Natural Resource Management in South and Central Asia. Sage Publications. New Delhi. ISBN: 81-7036-739-5.

[31] Li, B. 2012. From a Micro-Macro Framework to a MicroMeso-Macro Framework. In S.H. Christensen et al. (eds.), Engineering, Development and Philosophy, Philosophy of Engineering and Technology.

[32] Lin, N. 2002. Social Capital: A Theory of Social Structure and Action. Cambridge University Press.

[33] Lise, W. 2000. Factors influencing people's participation in forest management in India. Ecological Economics 34, 379 392.

[34] Macionis, J. J. 2001. Sociology (8th ed). Upper Saddle River, New Jersey: Prentice Hall.

[35] McAdam, D. 2004. "Revisiting the U.S. Civil Rights Movement: Toward a More Synthetic Understanding of the Origins of Contention.” Pp. 201-32 in Rethinking Social Movements: Structure, Meaning, and Emotion, edited by Jeff Goodwin and James Jasper. Oxford: Rowman and Littlefield Publishers.

[36] McAdam, D. and Snow, D. A. 1997. Social Movements: Readings on Their Emergence, Mobilization, and Dynamics is intended for use in courses on social movements, collective behavior, and political sociology. Oxford University Press.

[37] Meadows, D., Meadows, D. and Randers, J. 1992. Beyond the Limits: Confronting Global Collapse, Envisioning a Sustainable Future. Post Mills: Chelsea Green.

[38] Meffe, G., Ehrlich, A. and Ehrenfeld, D. 1993. 'Human Population Control: The Missing Agenda', Conservation Biology 7(1): 1-3.

[39] Miller, F. D. 1999. The end of SDS and the emergence of weatherman: Demise through success. In J. Freeman \& V. Johnson, (Eds.), Waves of protest: Social movements since the Sixties (pp. 303-324). Lanham, Maryland: Rowman \& Littlefield Publishers.

[40] Ministry of Environment and Forests (MoEF), 2007. The State of Environment Report - Orissa, 2007. Accessed online: http://envfor.nic.in/soer/state/SoE-orissa.pdf

[41] Mishra, A. 2012. Timber mafia rule forests. The Telegraph, Calcutta, India. Friday, July 27, 2012.

[42] Ministry of Environment and Forests (MoEF), 2007. State of Environment, State of the Enviornment Report - Orissa, 2007. MoEF, India.

[43] Mohanty, P. 2011. Conservation Reserve and Community Reserve in Odisha: A Study on the Potentials and Initiatives Taken so far. Regional Centre for Development Cooperation (RCDC), Odisha.

[44] Mohanty, P. C. 2006. Role of Community Participation through JFM for Rural Development in India. Strength Based Strategies - 2006.

[45] Murali, K.S., Rao R. J, and Ravindranath, N.H. 2003. Tropical Ecology. 44(1): 73-84.

[46] Murali, K.S., Sharma, M., Rao, R.J., Murthy, I.K., and Ravindranath, N.H., 2000. Status of participatory forest management in India: an analysis. In: N. H. Ravindranath, K. S. Murali \& K.C. Malhotra (eds.) Joint Forest Management and Community Forestry in India: An Ecological and Institutional Assessment. Oxford \& IBH Co., New Delhi. Pp 25-58.

[47] Myers, Norman (1991) 'The World's Forests and Human Populations: The Environmental Interconnections', in $\mathrm{K}$. Davis and M. Bernstam (eds) Resources, Environment, and Population: Present Knowledge, Future Options, pp. 237-51. New York: Oxford University Press.

[48] Nayak, P. K and Berkes, F. 2008. Politics of Co-Optation: Community Forest Management Versus Joint Forest Management in Orissa, India. Environmental Management (2008) 41:707-718.

[49] NDTV, 2010. Orissa villagers unite against timber mafia. NDTV, India, March, 22, 2010.

[50] Odisha Sun Times Bureau, 2011. Odisha has lost $9 \mathrm{sq} \mathrm{km}$ mangroves to prawn mafia, says green activist. Odisha Sun Times Bureau, Bhubaneswar, India, July, 11, 2011.

[51] Pattanaik, M. 2002. Community Forest Management in Orissa. RCDC, Community Forestry / Volume1 / Issue 1\&2 / January 2002.

[52] Poffenberger, M and Bhattacharya, P. 1996. Grassroots forest protection: Eastern Indian experiences. Center for Southeast Asian Studies, University of California, Berkeley.

[53] Poffenberger, M. and McGean, B. (eds), 1996: Village Voices, Forest Choices - Joint Forest management in India. Oxford University Press.

[54] Poffenberger, M. 1995: India's Forest Keepers. Wasteland News XI (1) Aug - Oct. New Delhi.

[55] Population Action International, 2011. Why Population Matters to Forests. Population Action International, Washington, DC. 
[56] Patro, B. and Jena, G. 2008. Forest Revenue of Orissa, Towards Tapping the Potential. Monograph Series-2. CYSD-Centre for Policy Research and Advocacy (CEPRA). CYSD, Bhubaneswar, Odisha.

[57] Putnam, R. 1993. Making Democracy Work, Princeton, NJ: Princeton University Press.

[58] Raju, G., 1998. Institutional Structures for Community-Based Conservation. In: Kothari et al. (eds.) Communities and Conservation. Natural Resource Management in South and Central Asia. Sage Publications. New Delhi. ISBN: 81-7036-739-5.

[59] Riyan, R. V. 2015. Timber smuggling rampant in the forests of Baripada. The Times of India, Bhubaneswar, May, 21, 2015.

[60] Sahu, S. K. 2010. Destroyed by Development. Infochange News \& Feature. India

[61] Sahu, S, C., Reddy, S, C., and Dhal, N, K. 2007. Phytosociological Study of Tropical Dry Deciduous Forest of Boudh District, Orissa, India. Research Journal of Forestry 1 (2): 66-72.

[62] Sangita, S. N. 2008. Social Capita in Forest Governance Regimes. Working Paper 190. Institute for Social and Economic Change (ISEC), Bangalore, India.

[63] Sarap, K., and Sarangi, T. 2009. Malfunctioning of Forest Institutions in Orissa. Economic \& Political Weekly, Vol XLIV no 37.

[64] Sarap, K. 2004. Participatory Forest Management in Orissa: A Review of Policies and Implementation. In Springate-Baginski, O (eds) Understanding Livelihood Impacts of Participatory Forest Management Implementation in India \& Nepal. University of East Anglia, UK.

[65] Sarin, M., Singh, N.M., Sundar, N. and R.K. Bhogal. 2003. Devolution as a threat to democratic decision making in forestry? Findings from three states in India. In: Edmunds, D. and E. Wollenberg (eds.) Local Forest Management: The Impacts of Devolution Policies. London, Sterling, VA: Earthscan.

[66] Sarin, M. 1996. Joint Forest Management: The Haryana Experience. Environment and Development Series, Centre for Environment and Education, Ahmedabad.

[67] Sarin, M. 1995. Joint Forest Management in India: Achievements and Unaddressed Challenges. Unasylva 46: 30-36.

[68] Sarin, M. 1994. Regenerating India's Forests: Reconciling Gender Equity with JFM. Paper presented at the International Workshop on India's Forest Management and Ecological Revival organized by the University of Florida and TERI, New Delhi 10-12 February.

[69] Saxena, N. C., 1997. The Saga of Participatory Forest Management in India. Center for International Forestry Research. Indonesia. ISBN 979-8674-15-3.

[70] Sekhar, M. 2004. Indigenous Institutions and Forest Conservation: User-Group Self-initiatives in India. Working Paper 140. Institute For Social And Economic Change, India

[71] Singh, K. D., Singh, J. P. and Sinha, B. 2008. Trends in forest ownership, forest resources tenure and institutional arrangements: Are they contributing to better forest management and poverty reduction? Understanding forest tenure in South and Southeast Asia. Case studies from Orissa, India. Food and Agriculture Organization of the United Nations

[72] Singh, K.D., Sinha, B. \& Mukherji, S.D. 2005. Exploring options for joint forest management (JFM) in India. Rome, FAO and Washington, DC, World Bank.

[73] Singh, S. K. 2002. Conflicts \& Disturbance - A reason to change: Lessons from Community based Natural Resource Management Institutions in Orissa, India. Paper to be presented in The 9th Biennial Conference of The International Association for the Study of Common Property. Victoria Falls, Zimbabwe - 17-21 June 2002.

[74] Singh, N. 2001. Women and Community Forests in Orissa: Rights and Management. Indian Journal of Gender Studies 8: 2 .

[75] Singh, N. 2000. Community Forest Management vs. Joint Forest Management in Orissa. Need to look beyond JFM.

[76] Srinivasan, K. 2004. Population and Development in India since independence: An overview. Population and Development, The Journal of Family Welfare, Vol. 50, Special Issue.

[77] Siripurapu, K. K. 2013. Participatory Forest Management Networks of Odisha- Time for more recognition. IUCN Newsletter. Accessed online: https://cmsdata.iucn.org/downl oads/kanna_community_based_netwroks_fra_epw_2__.p df

[78] Siripurapu, K. K., 2010. The Semantic of CFM - Peoples' Narration - Case Studies from Odisha. An effort to bring recognition and credibility to people's initiatives. First Edition 2010. Vasundhara, Bhubaneswar, Odisha.

[79] The Common Wealth Foundation Report, 2008. Commonwealth Forests - An overview of the Commonwealth's forest resources. Common Wealth Forestry Association, 2007.

[80] The Indian Census, 2011. Baudh (Boudh) District: Census 2011 data. Accessed online: http://www.census2011.co.in/ce nsus/district/415-baudh.html

[81] The New Indian Express, 2014. Mafia Take Forest Cover for Timber Smuggling. The New Indian Express, Tuesday, Dec' 4, 2014

[82] Vaidya, A. 2011. A history of forest regulations. Info Change India. Accessed online: http://infochangeindia.org/environm ent/backgrounder/a-history-of-forest-regulations.html

[83] Vasundhara, 2010. "Impact of Forest Development Agency on CFM systems in Orissa", (Draft Working Paper), Vasundhara, Bhubaneswar p-9.

[84] Vasundhara, 2005. Development Policies and Rural Poverty in Orissa: Macro Analysis and Case Studies. Vasundhara, India.

[85] Vasundhara, 1996. Community Forest Management in Transition: Role of the Forest Department and Need for Organizational Change. Mimeo. Bhubaneswar.

[86] Wilson, E. O. 1992. The Diversity of Life. New York: W. W. Norton. 
[87] Woolcock, M., 2000, 'Social Capital in Theory and Practice: Where do We Stand?' Paper prepared for the 21st Annual
Conference on Economic issues [World Bank social capital website]. 